\title{
Empowering Students' Abilities and Personalities through Student Librarians Programs
}

\author{
Stefana Evi Indrasari, S.S. \\ Sekolah Ciputra \\ Kawasan Puri Widya Kencana Kota Mandiri Citra Raya, Surabaya \\ Indonesia \\ evi@sekolahciputra.sch.id / vitoaxl@yahoo.com
}

\begin{abstract}
Learning Resource Centre will be a meaningful and engaging learning environment if there are interactions between librarians, students, teachers and all staff. Creating programs which involve students to be more active not only in the learning process but also in encouraging their abilities and talents will benefit them in the future. Having interesting and fun activities can be the best way to promote the library for all learners. Students as the main users of the library are introduced and welcomed to design programs that can make library more alive. This paper looks at the need of the students to develop and build up their confidence, creativity, commitment and enthusiasm as a part of the library and learning community.
\end{abstract}

\section{Keywords}

Student Librarian, Inter-personal skills, personality growth, teamwork, library program

\section{Understanding Human Personalities toward Students' Growth}

Looking at the child development cannot be separated from their personalities. They were born with their own characteristics. Some children are too shy, while the others are very diligent, and some children get along with others easily, but some dominate their friends. This is simply because every human was born with different personalities. Knowing what pupils want and the way they interact with others will help us understand their need. By learning their major and minor personalities we will find out about human interests and how to have fun with it.

Basically people are differentiated into four personalities, sanguine, melancholy, phlegmatic and choleric. Each person will have one dominant personality and followed by the other three minor personalities. These personalities are shaping the way they think, act, make a decision, and also interact with others (Littauer, 1992). A Sanguine child is very expressive and enthusiastic. $\mathrm{He}$ or she will mingle and get along with others so easily. However, this child cannot be given a lot of responsibilities, since he or she is forgetful and talkative. Moreover, she or he is a type of person who can only be given easy tasks of short duration. This is the opposite of a melancholy child. A Melancholy child has a very high standard for himself or herself. He or she is a perfectionist. Working with this type of student will give us a lot of benefits since he or she is an analytical and a creative person. However, if we want to work with this student we have to be careful because he or she has negative opinions of other students: he or she can be so sceptical, suspicious, and sometimes overly critical of other works. A Choleric student is 
different. He or she is a visionary person. Working with this type of student will allow us to explore ideas, set and achieve goals, and organize a lot of activities because this pupil is an energetic, dynamic, active, target oriented, free, and independent person. As a contrary this type of student likes to dominate others, is sometimes manipulative, and also a workaholic. If we want to work with this type of student, you will have to remind him or her to give chance to others and work as a team. The last personality is phlegmatic. Phlegmatic is a caring person. He or she is lovable, calm, patient, quiet and generous. He or she can be a problem solver, good administrator and good listener. This student tends to avoid conflicts and fights. However, if we want to work with this type of student we should be more patient because he or she works very slow, is sometimes too passive, and has less motivation and enthusiasm.

Having the knowledge of human personalities will enable us to work more easily with other people. By looking at their major personality and minor personalities we can find out how the students work, associate with others, and plan activities. This information can be used as a guideline for teacher librarian or librarian to design and promote the library program. One of the effective ways is by organizing and promoting Student Librarian Program.

\section{The Bright Sight of the Library in Developing Students' Abilities}

Library as a learning resource centre (LRC) is the same as the heart of the school. A school is considered as a great school if it can use its library to its full potential. One way to do this is by involving the students in the planning of every activity and program that the library has. Running a Student Librarians program is one way every school can use to make the library more alive

Student Librarians is an organization that a library can have to help students take ownership of their library. It is a voluntary program that is run by the students and for the students. The system in forming this organization is also based on students' willingness: if they are interested in this organization, they need to apply and follow all the qualifications including experiencing the selection, test, and interview session. The reason for having these steps in the selection process is to find out their sincerity and motivation in joining the program since they are going to have duty period of one year.

The members of student librarians are taken from year 3-5 for primary students, year 7-8 for secondary students, and year 10-11 for high school students. Students in these years are allowed to participate because of Indonesia's education policy regarding final exams for national curriculum in each level of education (primary, secondary, and high school) and we do not want the students' exam cycle to be interrupted with the SL program.

After the selection is finished, new student librarians will discuss their one year program including their regular meeting time, programs, ideas to make their library more colourful and useful, and budget needs. These conversations and processes are the most important and interesting part since we can see their abilities and personalities grow, especially when they need to work together as teamwork, or accept differences for the sake of everyone's needs. Student Librarians can develop programs for the school or community, and can serve as an example for other schools to promote the same programs, or find sister schools in order to expand students' knowledge.

The student-developed program can be a competition, charity, creativity, fair, or an excursion. One of the most favourite competitions is storytelling. It gives students not only the opportunity to perform, but also encourage them to be a risk taker and communicator. Moreover they are also challenged to be creative so that their story will not be too boring for the audiences. 
Holding a Book Fair is one of the best ways to gain new books for the collection for schools with a very minimal budget for their library resources. Book Fair can help raise funds and get donations not only from parents but also from book vendors. By inviting book vendors and selling stall space, for example, student librarians and the library can earn more money that they can use for adding resources.

Student librarians can also help students increase their self-esteem. Some shy and quiet students can improve their teamwork and leadership skills in this organization. This is simply because each member of student librarians engages in leadership every time they run a program. One good example is the workshop program, where each student shares their experience and knowledge with other students and teachers from other schools about their library. This is also talking about the information literacy lessons that they get in school. So at this point students not only develop their skills in public speaking, but also share their understanding and abilities with other students, which we hope can be shared again with other students in other schools creating a snow ball effect.

In conclusion, we need to realize that the library is a treasure land for students if we as teachers know how to use our library to support students' abilities and personalities. Basically children are like a blank page to write on. It depends on our creativity and willingness to help them grow to be more independent and to become life-long learners. Involving students in each program that we plan will help them grow and learn more. It does not matter how big our library is or how complete our collection is, but rather how we can empower them to learn and become someone with great meaning and life experiences.

\section{References}

Arnold, Ellen. 2000. MI Strategies for Kids: Featuring Brilliant Brain and Magnificent Mind. Tucson: Zepyr Press.

Barell, John. 2005. Developing More Curious Minds. Victoria: Hawker Brownlow Education.

Gawith, Gwen. 1987. Library Alive: Promoting Reading and Research in the School Library. London: A\&C Black.

Littauer, Florence. 1992. Personality Plus. New York: F.H. Revell Co.

Tomlinson, Carol Ann [et.al]. 2006. Integrating Differentiated Instruction and Understanding by Design. Alexandria: ASCD.

\section{Biographical note}

Stefana Evi Indrasari is a teacher librarian at Sekolah Ciputra, Surabaya, Indonesia. She has been working there for the last nine years. She spends her time to teach Information Literacy for primary students and develop a student librarian program in her school. She usually works with local schools around her school to develop their library and support the teachers from local schools to build up their own management system for their library, especially in helping them expanding the library programs for their students. You can contact her at evi@sekolahciputra.sch.id or vitoaxl@yahoo.com 